monthly number. Her useful life was no doubt shortened by overwork. In her.list of contributors she counted Hon. T. S. Parvin, of Cedar Rapids, the late Hon. A. R. Fulton, of this city, Hon. Irving B. Richman, of Muscatine, and others in our State. She was a capital converser, bright and witty when she chose to be-a person who left the pleasantest impressions upon all who met her-a rare woman, "of her gentle sex the seeming paragon." She lived in the New York Hotel, and though proprietors had come and gone, she retained the same rooms-surrounded by her rare and precious books-from the time she settled in that city, until her lamented death.

\title{
THE EVOLUTION OF A PUBLIC DOCUMENT.
}

There has been placed upon our table a bright and beautiful Iowa book of 208 pages, which seems to deserve appreciative notice in these pages. We refer to the "Iowa Official Register, I 893." An effort was made as long ago as I 860 to secure the publication of a legislative manual, largely a book of statistics, after the style of many of the older States, but the Legislature declined to print the booklet, even though its preparation was to cost nothing whatever! That this determination was a mistake, we do not believe any well-informed person would to-day question. But the initial point in this work was attained in 1864 , when Hon. James Wright, then Secretary of State, printed upon cards or loose sheets of paper the vote for the heads of the State tickets, giving also the population of the different counties. Only a limited number of copies, however, went into circulation. Succeeding Secretaries pursued much the same plan up to I 886 , when the "Official Register" began to appear in its present form, though much smaller in size. In 188 I Hon. J. A. T. Hull, then Secretary of State, had issued a very diminutive pamphlet of 32 pages, containing lists of the Executive and Judicial Officers of the State and the Trustees of public institutions. The size of the printed pages was but $21 / 4$ by 4 inches. Possibly in length it was one-sixteenth of an inch longer. It was a very small 
affair to be issued as a State document. But it was eagerly sought, and copies are now very scarce. It served an excellent purpose, however; not alone in the information presented, but as a step in the evolution of the beautiful book which we are now considering. In I $882 \mathrm{Mr}$. F. D. Reed, of Oskaloosa, prepared and published a Legislative Manual, a neat little volume of 194 pages, containing lists of public officers, rules of the House and Senate, and a variety of other information. It was really a very creditable work, but if our recollection is correct he had a rather hard time in getting any pay for the compilation. In I $88 \mathrm{I} \mathrm{Mr}$. Herbert S. Fairall, of The Iowa City Republican, began an annual publication called "The Manual of.Iowa Politics," with the design of making it what the "Official Register" has since become; but he discontinued it after a few years, owing, we presume, to the growing importance of the work at Des Moines, and the superior facilities for obtaining information at the Capital. While it appeared regularly it was received as an important and most useful annual, and copies are now in demand and difficult to obtain.

The present form was adopted in I 886, during the Secretaryship of Hon. Frank' D. Jackson. It was much smaller than at present, containing, in fact, but 92 pages. From that time forward it has steadily increased in size and the amount of useful. information it contains. During this period of its growth, Mr. C. S. Byrkit, Deputy Secretary of State, has had editorial charge of the publication. It is but just to say, that this work has met with the heartiest approval of the press and people throughout the State. In everything but size it will compare favorably with the best Annuali Registers or Manuals published by any of the older States. But, curiously enough, up to the last session of the General Assembly, the work had no. official sanction, the Secretaries of State having published it because it was so obviously needed-a real necessity-relying upon the Executive Council to pay for each successive issue. But at the last session, Hon. W. M. McFarland, Secretary of State, brought the matter to the attention of members, asking that the publication be duly authorized by law and made permanent. A law was therefore passed which provides for the 
publication and distribution annually of ten thousand copies. And thus this useful and beautiful annual volume has grown up from the smallest beginnings to its present solid foundation.

This eighth volume contains several new features of great interest. The frontispiece is a fine portrait of Gov. James W. Grimes. There are several cuts, including those of the different Iowa Capitol Buildings from the first. These will always possess much historic interest, and it has been a matter of some effort to obtain them. The Old Capitol in this city is shown as it appeared in its best days, and again after the fire of last autumn had converted it into a ruin. There is abundant information relating to the elections, the tickets and State and National party platforms, analytical statements of the vote in Iowa in 1892, by precincts and by congressional districts. Lists are given of State and county officers, and of the public institutions, with such further information as may properly be included in a work so largely statistical. The reader is also presented with information concerning the times of holding our courts, the Columbian Commission, the Military, the Governments of the States and Territories, the Public Schools, Libraries, etc.

This work, as stated, now stands upon a permanent foundation in law, but possibly better than this is the fact that it has met with such hearty approval by the people. Its appreciation is shown by the frequent demands for the early numbers, which are out of print. As the State increases in interests and population the "Official Record" will no doubt increase in size. The Ninth annual volume, the initial steps in the preparation of which have already been commenced, will be ready upon the meeting of the next Legislature. We do not doubt that it will contain new and useful features, as has each of its predecessors.

"Recollections of Iowa Men and Affairs," by Hon. Hiram Price, published in this number, will be read with interest by old-time citizens of our State. Few public men have wielded a more powerful personal influence in shaping the policy and advancing the material interests of our State than Hiram Price. 
Copyright of Annals of Iowa is the property of State of Iowa, by \& through the State Historical Society of Iowa and its content may not be copied or emailed to multiple sites or posted to a listserv without the copyright holder's express written permission. However, users may print, download, or email articles for individual use. 